\title{
'n Kort samevatting van die bespreking na die voorafgaande referate
}

\author{
APB BREYTENBACH
}

1. Al die sprekers was dit eens oor die houdbaarheid van die teologie wat grondliggend is aan die kinderdoop. Op geen stadium is daar enige bedenkinge uitgespreek oor die kinderdoop as sodanig nie. Verskeie sprekers het klem gelê op die troos en bemoediging wat juis deur die kinderdoop gebied word aan gelowiges.

2. Oor die tradisionele begronding van die kinderdoop met 'n verbondsteologie, het die menings uiteengegaan: Aan die een kant van die spektrum was daar sprekers wat van mening was dat die tradisionele begronding van die kinderdoop deur die verbond, asook die Skrifbeskouing en -gebruik wat daaraan ten grondslag lê, volkome aanvaarbaar is. Aan die ander kant van die spektrum was daar die standpunt dat die Skrifbeskouing en -gebruik wat die tradisionele verbondsteologie onderbou, op bepaalde punte ernstig bevraagteken kan word en dat daar ook bedenkinge geopper kan word oor die bruikbaarheid van die verbond as teologiese kategorie om uitdrukking te gee aan die verhouding tussen God en mens waaroor dit in die Nuwe Testament gaan. Tussen hierdie twee standpunte was daar 'n hele reeks moontlikhede soos byvoorbeeld dat die tradisionele Skrifbeskouing en -gebruik onaanvaarbaar is, maar dat die verbond tòg ' $n$ bruikbare en legitieme teologiese kategorie is om oor die verhouding tussen God en mens te praat.

3. Verskeie sprekers het dit onder woorde gebring en dit was ook uit die verloop van die bespreking duidelik dat daar nog baie studiewerk oor die onderwerp voorlê. In dic referate en bespreking is die grense en breë kontoere van die landskap maar net verken. Sake wat veral uitgewys is as verdere studieterreine is:

- Die verhouding tussen die Ou en die Nuwe Testament veral met betrekking tot die kontinuïteit en/of diskontinuïteit tussen die twee korpusse;

- die kontinuïteit en/of diskontinuïteit tussen God se verhouding met Israel en sy verhouding met die gelowiges van die Nuwe-Testamentiese tyd;

- die voorkoms en belang van die verbond in die Nuwe Testament. 
Sommige sprekers het daarop gewys dat hierdie studiewerk wat nog gedoen moet word uiteindelik daarop moet uitloop dat die saak van die kinderdoop en die verbond in óns tyd en met óns wetenskaplike kennis van die Bybel, sonder die aksente van vergange polemieke nuut verwoord moet word. Dit is duidelik gestel dat so 'n nuwe verwoording na alle waarskynlikheid niks sal verander aan die wesenlike van die teologie wat ten grondslag van die kinderdoop lê nie, maar dat die wyse van begronding daar anders kan uitsien.

4. Dit was duidelik dat die teologiese klimaat in die Nederduitsch Hervormde Kerk gunstig is vir' $n$ onbevange ondersoek van genoemde sake en vir 'n eerlike soeke na antwoorde op die probleme wat met die simposium na vore gekom het. Aan die een kant is daar nie by predikante en akademici die begeerte om met die teologiese tradisie waarin die kerk staan, te breek nie. Aan die ander kant is juis die reformatoriese gees wat die kerk se tradisie help skep het, lewendig in dié sin dat daar op akademiese vlak en met 'n oop gemoed na die Bybel geluister word, al sou dit ook beteken dat hierdie luister na die Bybel die kerk se eie teologiese tradisie onder kritiek plaas. 